Article

\title{
A Naked-Eye Visible Colorimetric and Ratiometric Chemosensor Based on Schiff Base for Fluoride Anion Detection
}

\author{
Liu Yang 1,+, Yu-Long Liu 1,+, Cheng-Guo Liu ${ }^{2}$, Ying Fu 1,* and Fei Ye 1,* \\ 1 Department of Applied Chemistry, College of Arts and Sciences, Northeast Agricultural University, \\ Harbin, 150030, People's Republic of China. \\ 2 Department of State Assets Management, Northeast Agricultural University, Harbin, 150030, People's \\ Republic of China. \\ * Correspondence: fuying@neau.edu.cn; yefei@neau.edu.cn; Tel.: +86-451-55190070 \\ + These authors contributed equally to this work.
}

\begin{abstract}
A dual-platform colorimetric and ratiometric chemosensor, namely 6-(2hydroxynaphthalen)- $N$-n-butyl-naphthalimide (HNA), based on Schiff base constructed from $N$-nbutyl-4-amino-1,8-naphthalimide and 2-hydroxy-1-naphthaldehyde has been designed and fabricated for detecting fluoride anion ( $\left.\mathrm{F}^{-}\right)$in DMSO solution. HNA is a colorimetic and ratiometric probe with superior selectivity and sensitivity. The color changes of HNA from yellow to purple was observed by the naked eyes in the presence of $\mathrm{F}^{-}$. The absorbance in the UV-Vis spectra of HNA was decreasing in $422 \mathrm{~nm}$, while gradually increasing in $583 \mathrm{~nm}$ by adding $\mathrm{F}^{-}$. The limit of detection (LOD) of HNA for detecting $\mathrm{F}^{-}$is low to $0.61 \mu \mathrm{M}$ and the binding model of HNA and $\mathrm{F}^{-}$is in 3:2 stoichiometry. Meanwhile, HNA can be used to detect $\mathrm{F}^{-}$in real samples. Finally, the mechanism of HNA for the detection of $\mathrm{F}^{-}$was investigated. The present work indicated that HNA would be a superior potential chemosensor in monitoring $\mathrm{F}^{-}$selectively and sensitively.
\end{abstract}

Keywords: Colorimetric; Ratiometric; Chemosensor; Fluoride anion detection; Naked-eye visible

\section{Introduction}

Fluoride anion exists everywhere in nature and organisms, which is the most electronegative atom with the smallest radius and the highest charge density [1-4]. Fluoride anion has stimulated the increasing interests of researchers owing to its extensive applications in the osteoporosis treatment, tooth protection, nerve agents detection and insecticides preparation, etc [5-8]. Fluoride anion is beneficial or harmful relying on its intake. Excessive intake of fluoride anion can result in urolithiasis, teeth and bone damage, systemic diseases of cardiovascular and nervous system, kidney infection, and nephrotoxic changes, etc [9-12]. The concentration of fluoride anion up to $50 \mu \mathrm{M}$ in drinking water can prevent tooth decay, and up to $250 \mu \mathrm{M}$ can cause teeth and bone damage [13,14]. Based on the harm of excessive intake of fluoride ion, the Environmental Protection Agency (EPA, USA) proposed that the concentration of fluoride anion at $2 \mathrm{mg} \mathrm{L}^{-1}$ and $4 \mathrm{mg} \mathrm{L}^{-1}$ were the non-enforceable and enforceable drinking water standard [15]. Hence, exploring sensitive and effective technologies for detecting fluoride anion is strongly urgent.

Up to now, lots of methods have been exploited for the detection of fluoride anion, such as ${ }^{19} \mathrm{~F}$ NMR, molecular absorption spectrometry (MAS), atomic absorption spectrometry (AAS), and chromatography-mass spectrometry [16-20]. Although these technologies are very mature, they need complicated operation, professional operator, high expense and complicated data analyses.

Colorimetric sensors are regarded as one of the most effective and convenient methods for detecting inorganic ions, organic small molecules, pesticides, toxic vapor and so on [21-24]. Colorimetric sensors detection is dependent on the color variation of the analytes observed by naked eyes, where guests and colorimetric sensors are bound together with different forces. There are many structures used to build colorimetric sensors, such as anthracene, naphthalene, indole, dansyl and imidazole, etc [25-30]. The advantages of colorimetric sensors are fast response, high sensitivity, good 
selectivity, simple operation and data analyses, reasonable price and intuitive color changes by naked eyes [31]. Ratiometric sensors take the ratio of the absorption or emission intensities at two wavelengths as signals and usually provide a higher accuracy in quantitative analyses. Ratiometric sensors can eliminate the influence of external environment, detection substrate and photobleaching, probe loading and retention during the experiment [32]. To date, some colorimetric and ratiometric chemosensors for detecting fluoride anion were reported, which are mostly based on the intermolecular interactions, such as desilylation of $\mathrm{Si}-\mathrm{O} / \mathrm{Si}-\mathrm{C}$ bonds, $\mathrm{B}-\mathrm{F}$ complexation and hydrogen bonding interaction [33-36].

In this work, $N$-n-butyl-4-amino-1,8-naphthalimide and 2-hydroxy-1-naphthaldehyde were chosen to construct a dual-platform colorimetric and ratiometric chemosensor, namely 6-(2hydroxynaphthalen)-N-n-butyl-naphthalimide (HNA), for the detection of fluoride anion in DMSO solution. The color changes of HNA from yellow to purple in DMSO solution was observed by the naked eyes in the presence of fluoride anion. HNA is a ratiometric chemosensor with the absorbance of the UV-vis spectra decreasing in $422 \mathrm{~nm}$ and increasing in $583 \mathrm{~nm}$ by adding fluoride anion. The LOD of HNA for detecting fluoride anion is extremely low and HNA can be used to detect fluoride anion in real samples. The mechanism of HNA for detecting fluoride anion has been investigated.

\section{Results and Discussion}

\subsection{Colorimetric experiments}

The UV-Vis spectra of $\mathrm{HNA}\left(10^{-5} \mathrm{M}\right)$ towards $\mathrm{F}^{-}$and other anions $\left(\mathrm{Cl}^{-}, \mathrm{Br}^{-}, \mathrm{I}^{-}, \mathrm{NO}_{3}^{-}, \mathrm{HSO}_{4}^{-}, \mathrm{SCN}^{-}\right.$ and $\mathrm{ClO}_{4}^{-}$) in TBA salts have been investigated in DMSO solutions. In Figure 1a, the maximum absorption peaks of HNA and HNA with other anions (15 equiv.) were all at $422 \mathrm{~nm}$ in the UV-Vis spectra. Once adding 15 equiv. $(150 \mu \mathrm{L}) \mathrm{F}^{-}$, the maximum absorption peak of HNA was red-shifted to $583 \mathrm{~nm}$, where the color of HNA solution turned from yellow to purple observed by naked eyes, while HNA solutions in the presence of other anions showed no obvious changes (Figure 1b).

(a)

(b)

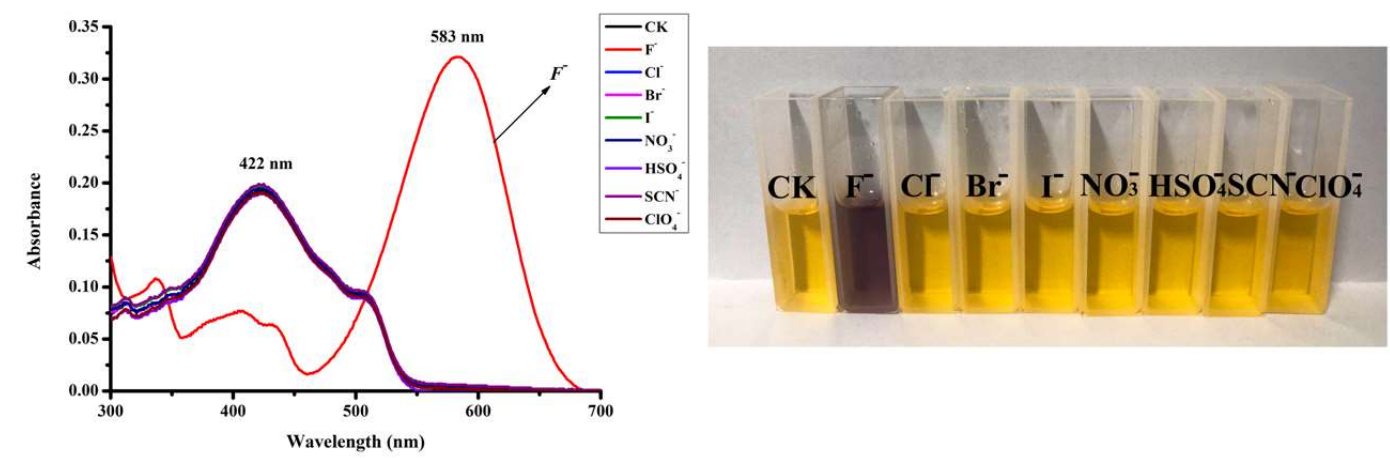

Figure 1. (a) UV-Vis spectra of $\mathrm{HNA}\left(10^{-5} \mathrm{M}\right)$ in the presence of 15 equiv. $\mathrm{F}^{-}, \mathrm{Cl}^{-}, \mathrm{Br}^{-}, \mathrm{I}^{-}, \mathrm{NO}_{3}^{-}, \mathrm{HSO}_{4}^{-}$, $\mathrm{SCN}^{-}$and $\mathrm{ClO}_{4}^{-}$. (b) Color changes of $\mathrm{HNA}\left(10^{-5} \mathrm{M}\right)$ in DMSO with adding 15 equiv. $\mathrm{F}^{-}, \mathrm{Cl}^{-}, \mathrm{Br}^{-}, \mathrm{I}^{-}$, $\mathrm{NO}_{3}{ }^{-}, \mathrm{HSO}_{4}{ }^{-}, \mathrm{SCN}^{-}$and $\mathrm{ClO}_{4}{ }^{-}$.

\subsection{The spectral properties of $\mathbf{H N A}$ for the detection of $F^{-}$}

In order to further study the ability of HNA for the detection of $\mathrm{F}^{-}$as a selective chemosensor, the competitive experiments were carried out. The maximum absorption of HNA in DMSO solution displayed no obvious decreased after adding 15 equiv. other anions. As listed in Figure 2, the maximum absorption peaks of HNA solutions with $\mathrm{F}^{-}$and with $\mathrm{F}^{-}$and other anions all centered at $583 \mathrm{~nm}$, which implied that HNA would not be interfered by coexisting anions, the existance of $\mathrm{F}^{-}$ 
induced the changes of UV-Vis spectra and HNA would be a selective chemosensor for detecting $\mathrm{F}^{-}$. The colors of HNA solutions with $\mathrm{F}^{-}$and with $\mathrm{F}^{-}$and other anions all changed from yellow to purple.

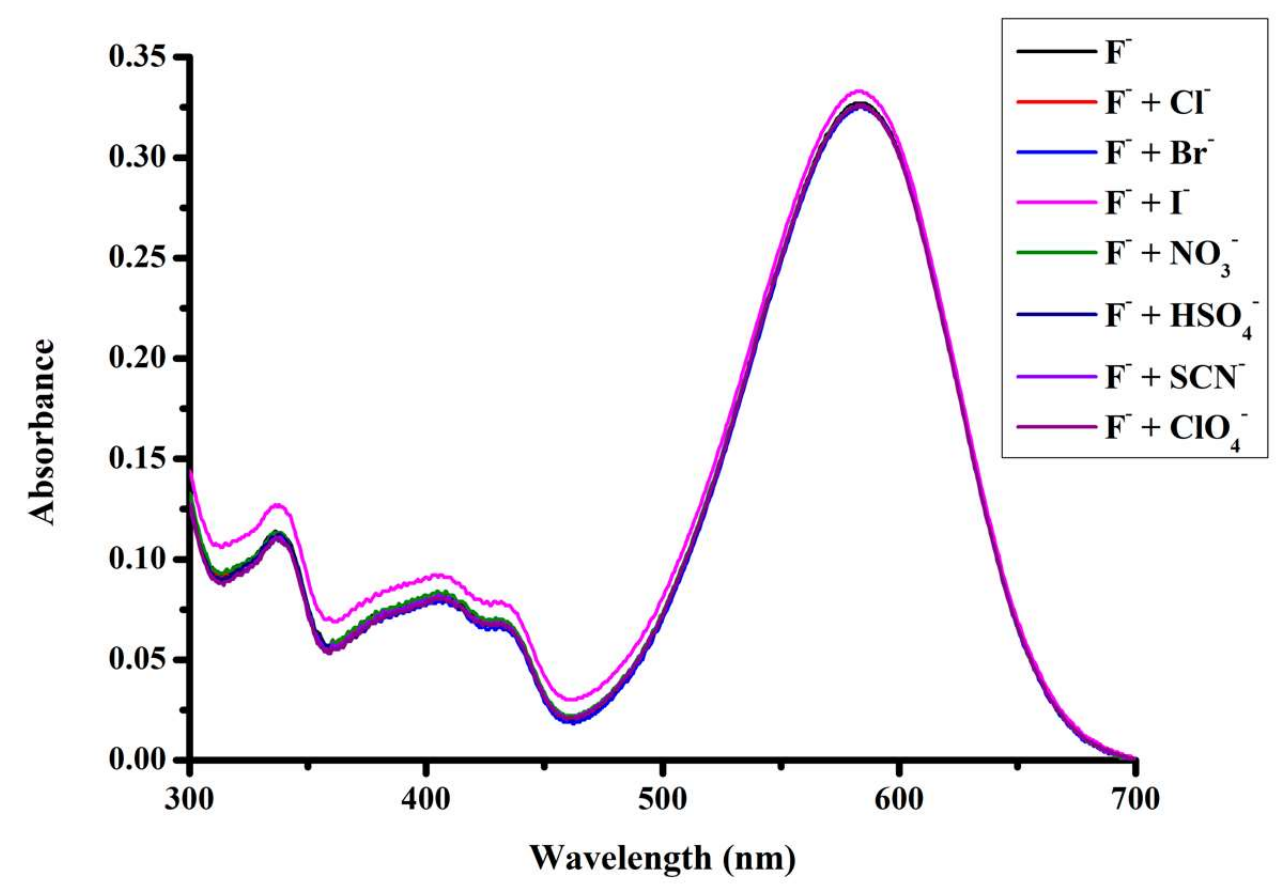

Figure 2. UV-Vis spectra of HNA $\left(10^{-5} \mathrm{M}\right)$ after adding 15 equiv. other anions in DMSO.

Next, an increasing amount of $\mathrm{F}^{-}$ranging from 0 to 16 equiv. was added to the solution of HNA $\left(10^{-5} \mathrm{M}\right)$ and $\mathrm{UV}-\mathrm{Vis}$ spectra was measured by titration experiments. The maximum absorption peak at $422 \mathrm{~nm}$ decreased gradually, while the main peak at $583 \mathrm{~nm}$ appeared and increased (Figure 3a). The absorbance peak reached to the maximum with the concentration of $\mathrm{F}^{-} 15$ equiv. Obviously, 161 $\mathrm{nm}$ red shift in the UV-Vis spectra resulted in the color changes of HNA solution by naked eyes, which is a colorimetric and ratiometric chemosensors. Meanwhile, there existed an excellent linear relationship between the ratiometric values $\left(A_{583} / A_{422}\right)$ and the concentration of $\mathrm{F}^{-}$(Figure $3 \mathrm{~b}$ ). The LOD of HNA for detecting $\mathrm{F}^{-}$was low to $0.61 \mu \mathrm{M}$, which was calculated based on the equation of $\mathrm{LOD}=3 \sigma / S$. In the equation, $S$ is meaning of the slope of the calibration and $\sigma$ is the standard deviation of the response in blank samples without $\mathrm{F}^{-}[37,38]$. Notably, the LOD of HNA for detecting $\mathrm{F}^{-}$is much lower than the limit value in pollutant level for the detection of $\mathrm{F}^{-}(210 \mu \mathrm{M})$ proposed by the US Environmental Protection Agency (EPA) [39]. Some reported chemosensors for the detection of $\mathrm{F}^{-}$have been compared with HNA in Table 1 [40-44].

(a)

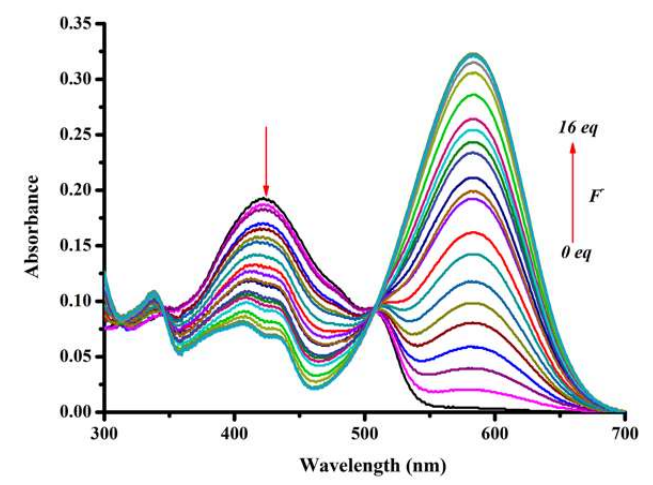

(b)

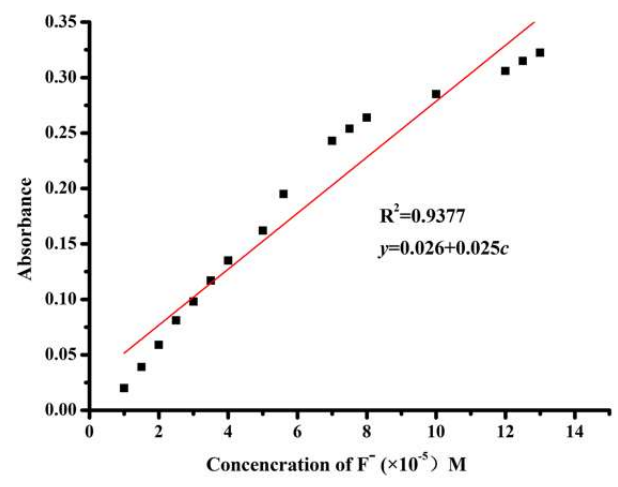


Figure 3. (a) UV-Vis spectra of HNA $\left(10^{-5} \mathrm{M}\right)$ with the different concentrations of $\mathrm{F}^{-}$added. (b) The linearity between the values of absorption and the concentrations of $\mathrm{F}^{-}$.

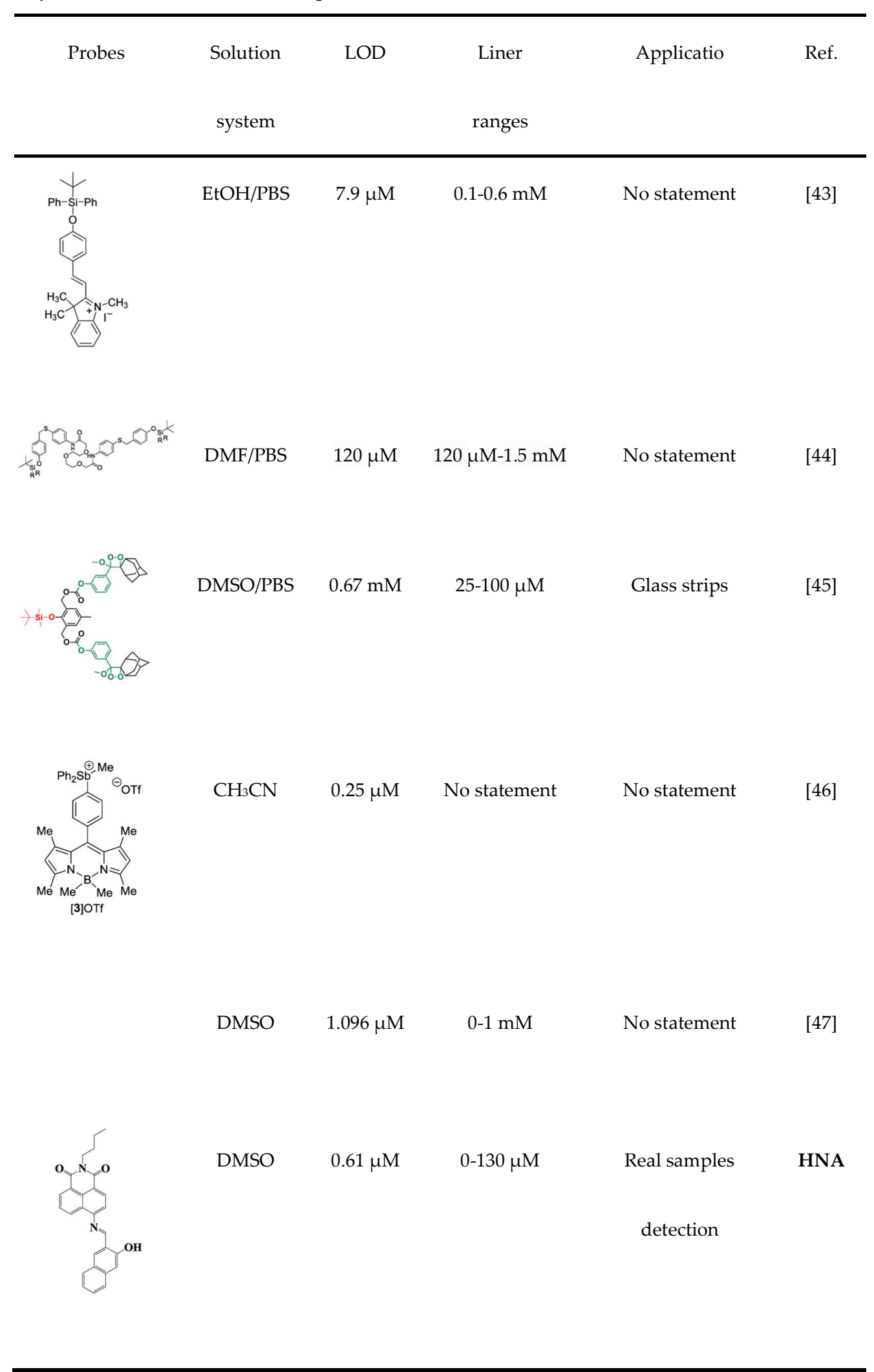

Table 1. Comparison of HNA with other reported sensors for the detection of $\mathrm{F}^{-}$. 
Finally, Job's plot has been introduced to investigate the stoichiometric proportion of HNA and $\mathrm{F}^{-}$. In the the Job's plot, the maxima peak was at 0.6 in DMSO solution, which was based on the formula of $\left[\mathrm{F}^{-}\right] /\left(\left[\mathrm{F}^{-}\right]+[\mathrm{HNA}]\right)$ (Figure 4$)$. The data implied that the ratio of interaction between HNA and $\mathrm{F}^{-}$was 3:2.

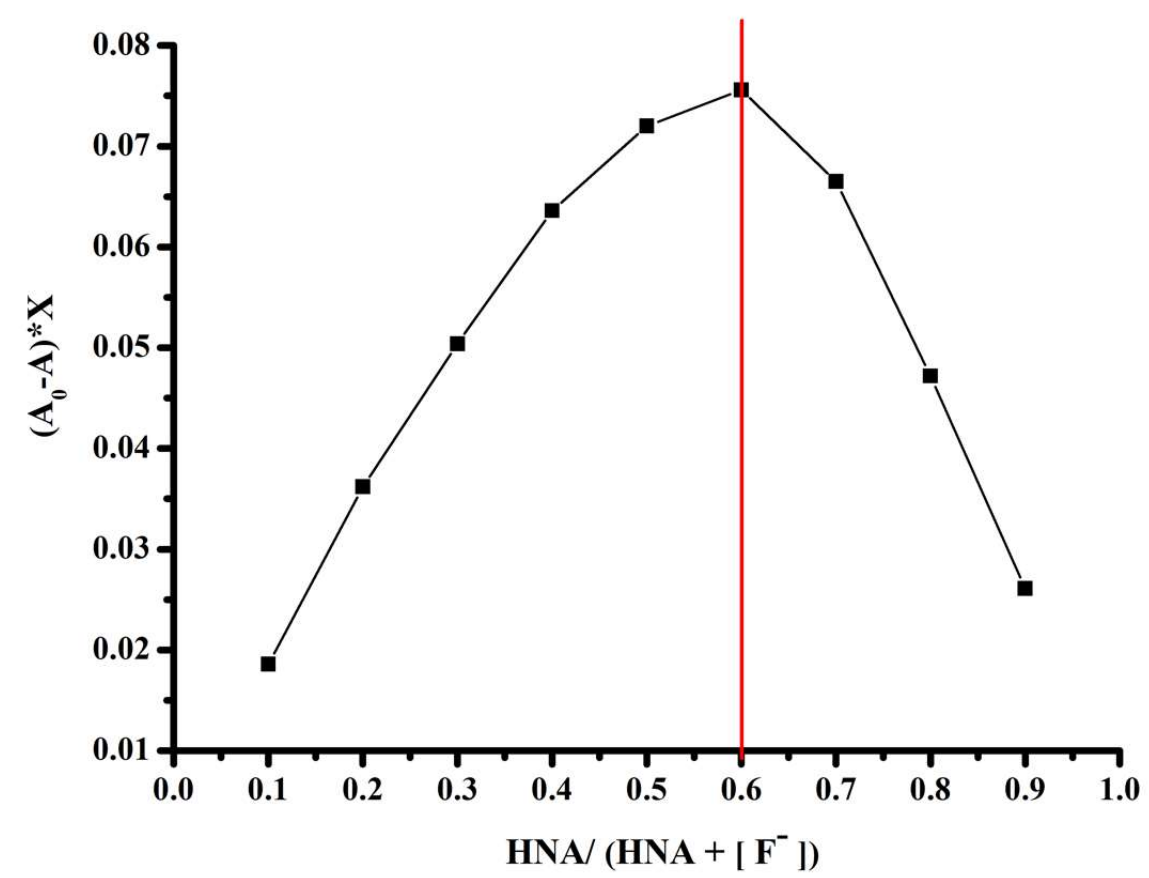

Figure 4. The Job's plot of HNA (583 nm) with $\mathrm{F}^{-}$determined in DMSO by UV-Vis spectra.

\subsection{Detecting $F^{-}$in real samples}

HNA sensor has been selected to detect $\mathrm{F}^{-}$in real samples. In this work, the standard addition method for the detection of $\mathrm{F}^{-}$was chosen and the water source was collected from the local water of the Songhua river. The final concentrations of $\mathrm{F}^{-}$in the water samples were $1.0 \mu \mathrm{M}, 5.0 \mu \mathrm{M}, 10.0 \mu \mathrm{M}$, $50.0 \mu \mathrm{M}$ and $100.0 \mu \mathrm{M}$, and UV-Vis spectra and linear normalization equation were used to value the data reliability for the detection of $\mathrm{F}^{-}$. The data are listed in Table 2, where the recoveries of HNA for detecting $\mathrm{F}^{-}$were ranging from $96.1 \%$ to $104.6 \%$ and all RSD values were all within $3.98 \%$. These data implied that HNA as a chemosensor for the detection of $\mathrm{F}^{-}$in real samples is precise and feasible.

\begin{tabular}{ccccc} 
HNA & Add $(\mu \mathrm{M})$ & Found $(\mu \mathrm{M})$ & Recovery $(\%)$ & RSD $^{\mathrm{b}}(\%)$ \\
\hline \multirow{3}{*}{ Songhua river } & 0.1 & $0.103 \pm 0.002$ & $101.3 \pm 2.0$ & 3.66 \\
& 1.0 & $1.046 \pm 0.019$ & $104.6 \pm 1.9$ & 1.59 \\
& 5.0 & $4.836 \pm 0.103$ & $96.7 \pm 2.1$ & 3.98 \\
& 10.0 & $9.794 \pm 0.287$ & $97.9 \pm 2.9$ & 2.19 \\
& 50.0 & $48.051 \pm 1.165$ & $96.1 \pm 2.3$ & 2.72 \\
& 100.0 & $100.76 \pm 2.311$ & $100.8 \pm 2.3$ & 1.83
\end{tabular}

Average of three repeated measurements of $\mathrm{F}^{-}$. ${ }^{\mathrm{b}} \mathrm{RSD}$ means relative standard deviation.

Table 2. Results of detecting $\mathrm{F}^{-}$in real samples. 


\subsection{The mechanism of $\mathbf{H N A}$ for the detection of $F^{-}$}

The possible mechanism of HNA for the detection of $\mathrm{F}^{-}$is the hydrogen bond interaction between HNA and $\mathrm{F}^{-}$at low concentrations, while deprotonation of $\mathrm{O}-\mathrm{H}$ proton at high concentrations of $\mathrm{F}^{-}$ (Scheme 1).

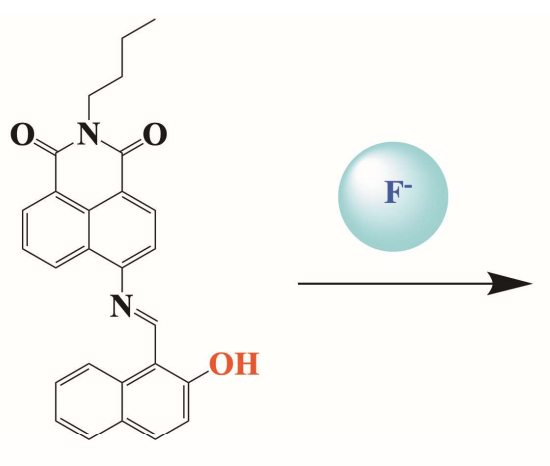

HNA

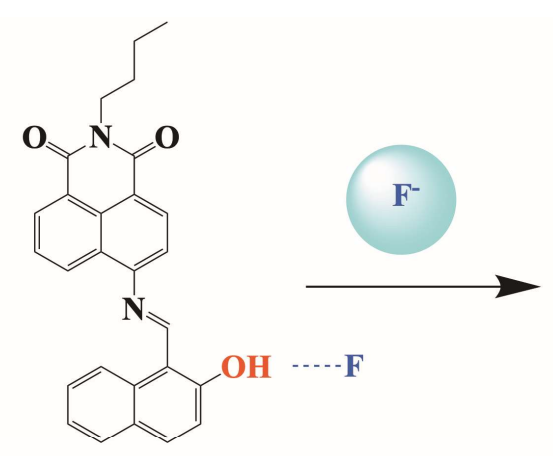

HNA+F-

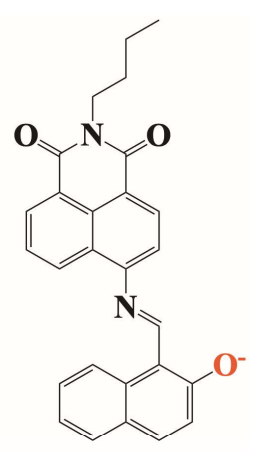

$\mathrm{HNA}^{-}+\mathrm{HF}$

Scheme 1. The possible mechanism of HNA for the detection of $\mathrm{F}^{-}$.

To investigate this mechanism of HNA for detecting $\mathrm{F}^{-}$in detail, the orbital energies of HOMO1, HOMO (highest occupied molecular orbital), LUMO (lowest unoccupied molecular orbital) and LUMO+1 of HNA, HNA+F- and $\mathbf{H N A}^{-}$have been calculated by the method of DFT (density

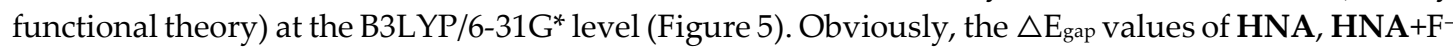
and HNA $^{-}$were $0.325 \mathrm{eV}, 0.090 \mathrm{eV}$ and $0.085 \mathrm{eV}$, respectively, which decreased gradually. The electron affinities of $\mathbf{H N A}+\mathrm{F}^{-}$and $\mathbf{H N A}^{-}$were relatively higher than $\mathbf{H N A}$, resulting in the transfer

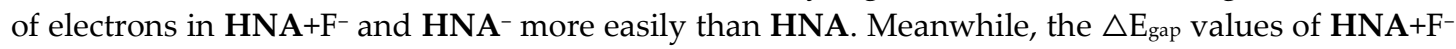
and HNA $^{-}$were smaller than HNA, and it implied that the interaction between $\mathbf{H N A}$ and $\mathrm{F}^{-}$was hydrogen bond, while deprotonation at high concentration of $\mathrm{F}^{-}$[45-47]. Furthermore, the electrons transitions of $\mathbf{H N A}+\mathrm{F}^{-}$and $\mathbf{H N A}^{-}$in $\mathrm{HOMO}-1 \rightarrow$ LUMO and $\mathrm{HOMO} \rightarrow \mathrm{LUMO}+1$ may produce the same results.

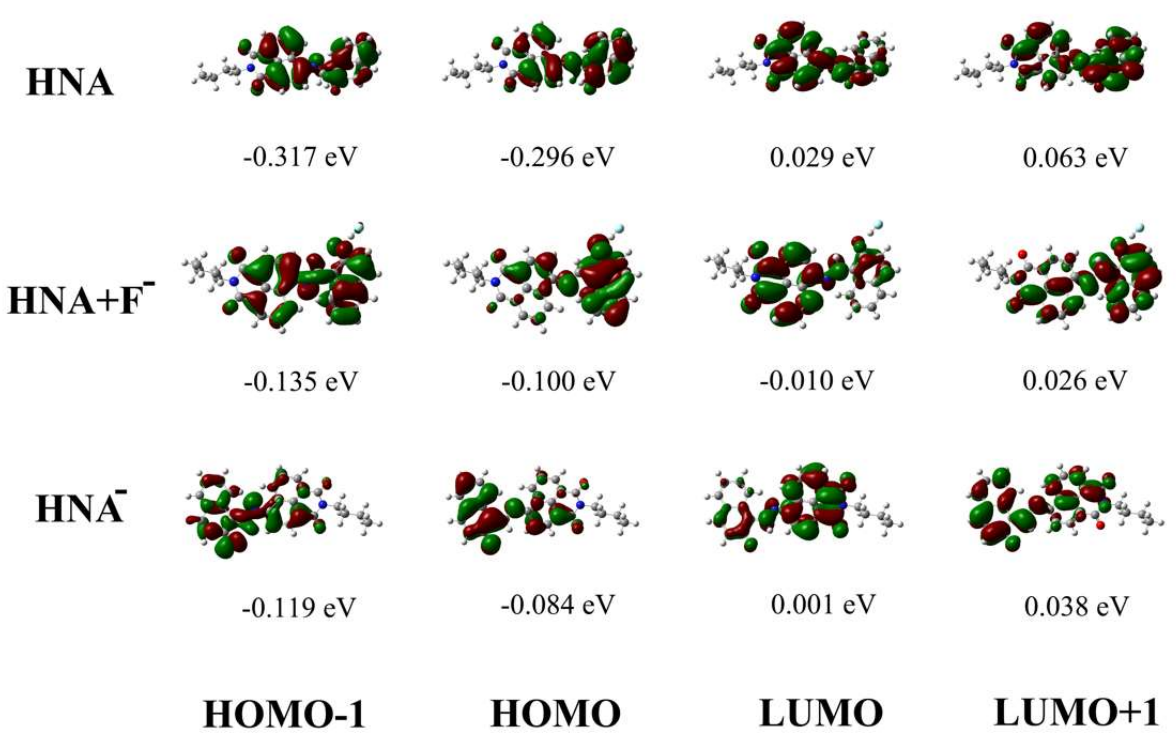

Figure 5. Molecular orbital shapes and energies of HOMO-1, HOMO, LUMO and LUMO+1. 


\section{Materials and Methods}

\subsection{Materials and physical measurement}

All the reactants and solvents used in this work were commercially available without purification. Anions of $\mathrm{F}^{-}, \mathrm{Cl}^{-}, \mathrm{Br}^{-}, \mathrm{I}^{-}, \mathrm{NO}_{3}^{-}, \mathrm{HSO}_{4}^{-}, \mathrm{SCN}^{-}$and $\mathrm{ClO}_{4}^{-}$in this work were obtained from tetrabutylammonium (TBA) salts and purchased from Sigma-Aldrich. Dimethyl sulfoxide (DMSO) was purchased from Aladdin. High resolution mass spectrometer (HRMS) was measured on Agilent 6224. The ${ }^{1} \mathrm{H}$ NMR spectra were tested on a Bruker AVANVE $400 \mathrm{MHz}$ nuclear magnetic resonance spectrometer (Bruker, Germany) utilizing $\mathrm{CDCl}_{3}$ and $\mathrm{DMSO}-\mathrm{d}_{6}$ as the solvents, where TMS is the internal standard. The fusion points were recorded on Shanghai Inesa melting point apparatus (WRS3) without correction. Finally, UV-Vis spectra were measured with the range of wavelengths from $200 \mathrm{~nm}$ to $800 \mathrm{~nm}$ on a Shimadzu UV-2700 spectrophotometer.

\subsection{Synthesis}

\subsubsection{Synthesis of 4-nitro-N-n-butyl-1,8-naphthalimide (2)}

A mixture of 4-nitro-1,8-naphthalic anhydride $(1.22 \mathrm{~g}, 5 \mathrm{mmol})$ and $n$-butylamine $(0.60 \mathrm{~g}, 8$ $\mathrm{mmol}$ ) were dissolved in ethanol solution $(75 \mathrm{~mL})$, then the reaction were reflux at $80{ }^{\circ} \mathrm{C}$ for $4 \mathrm{~h}$. After cooling to room temperature, the mixture was removed in vacuum to obtained crude compound. And then the crude compound was purified used silica column chromatography (EtOAc/petroleum ether, $1: 30 \mathrm{v} / \mathrm{v}$ ) to give a yellow solid was compound 2 [48]. Yield: $43 \%$. m.p.: 106.4-107.2 ${ }^{\circ} \mathrm{C} .{ }^{1} \mathrm{H}$ NMR $\left(400 \mathrm{MHz}, \mathrm{CDCl}_{3}\right) \delta 8.83(\mathrm{~d}, J=8.7 \mathrm{~Hz}, 1 \mathrm{H}), 8.71(\mathrm{dd}, J=18.6,7.6 \mathrm{~Hz}, 2 \mathrm{H}), 8.40(\mathrm{~d}, J=8.0 \mathrm{~Hz}, 1 \mathrm{H}), 7.95-$ $8.03(\mathrm{~m}, 1 \mathrm{H}), 4.02-4.31(\mathrm{~m}, 2 \mathrm{H}), 1.73(\mathrm{t}, J=7.6 \mathrm{~Hz}, 2 \mathrm{H}), 1.39-1.54(\mathrm{~m}, 2 \mathrm{H}), 0.95-1.02(\mathrm{~m}, 3 \mathrm{H})$ (Figure S1).

\subsubsection{Synthesis of 4-amino-N-n-butyl-1,8-naphthalimide (3)}

4-nitro- $N$-n-butyl-1,8-naphthalimide $(0.95 \mathrm{~g}, 2.7 \mathrm{mmol})$ was dissolved in methanol (45 $\mathrm{mL})$, then the $\mathrm{Pd} / \mathrm{C}(0.3 \mathrm{~g})$ was added to the solution. The reaction was conducted under hydrogen atmosphere in a high-pressure reactor for $2 \mathrm{~h}$. Then it was filtered through a pad of celatom. The solvent was concentrated under vacuum to given an orange solid was compound 3 [49]. Yield: 91 \%. m.p.: 181.9$182.2{ }^{\circ} \mathrm{C} .{ }^{1} \mathrm{H}$ NMR $\left(400 \mathrm{MHz}, \mathrm{CDCl}_{3}\right) \delta 8.59(\mathrm{~d}, J=6.9 \mathrm{~Hz}, 1 \mathrm{H}), 8.41(\mathrm{~d}, J=8.1 \mathrm{~Hz}, 1 \mathrm{H}), 8.12(\mathrm{~s}, 1 \mathrm{H})$, 7.58-7.69 (m, 1H), $6.88(\mathrm{~d}, J=8.1 \mathrm{~Hz}, 1 \mathrm{H}), 4.15(\mathrm{~d}, J=7.6 \mathrm{~Hz}, 2 \mathrm{H}), 1.71(\mathrm{t}, J=7.6 \mathrm{~Hz}, 2 \mathrm{H}), 1.36-1.51(\mathrm{~m}$, $2 \mathrm{H}), 0.97(\mathrm{t}, J=7.4 \mathrm{~Hz}, 3 \mathrm{H})$ (Figure S2).

\subsubsection{Synthesis of $\mathbf{H N A}$}

4-amino- $N$-n-butyl-1,8-naphthalimide $(1.44 \mathrm{~g}, 1.2 \mathrm{mmol})$ was dissolved in ethanol solution (50 $\mathrm{mL})$ and then 2-hydroxy-1-naphthaldehyde $(2.06 \mathrm{~g}, 1.2 \mathrm{mmol})$ was added to the solution. The reaction was reflux at $85^{\circ} \mathrm{C}$ for $12 \mathrm{~h}$. After the reaction was completed, the solvent was removed to obtained the crude product. Then the crude product was purified used silica column chromatography (EtOAc: petroleum ether, 1:20 v/v) to obtained HNA as orange solid [50] (Scheme 2). Yield: 42\%. m.p.: 242.4$243.7^{\circ} \mathrm{C} .{ }^{1} \mathrm{H} \mathrm{NMR}\left(400 \mathrm{MHz}, \mathrm{CDCl}_{3}\right) \delta 9.63$ (s, $\left.1 \mathrm{H}\right), 8.68(\mathrm{~d}, J=15.2 \mathrm{~Hz}, 3 \mathrm{H}), 8.24(\mathrm{~d}, J=8.5 \mathrm{~Hz}, 1 \mathrm{H})$, $7.96(\mathrm{~d}, J=9.1 \mathrm{~Hz}, 1 \mathrm{H}), 7.83(\mathrm{t}, J=8.4 \mathrm{~Hz}, 2 \mathrm{H}), 7.63-7.54(\mathrm{~m}, 2 \mathrm{H}), 7.43(\mathrm{~d}, J=7.8 \mathrm{~Hz}, 1 \mathrm{H}), 4.24-4.18(\mathrm{~m}$, $2 \mathrm{H}), 1.77(\mathrm{~s}, 2 \mathrm{H}), 1.48(\mathrm{~d}, J=7.6 \mathrm{~Hz}, 2 \mathrm{H}), 1.00(\mathrm{t}, J=7.4 \mathrm{~Hz}, 3 \mathrm{H})$ (Figure S3); HRMS (ESI): $\mathrm{m} / z$ calcd. for $\mathrm{C}_{27} \mathrm{H}_{22} \mathrm{~N}_{2} \mathrm{O}_{3}$ : $423.17032\left([\mathrm{M}+\mathrm{H}]^{+}\right)$, found: 423.17086 (Figure $\mathrm{S} 4$ ). 


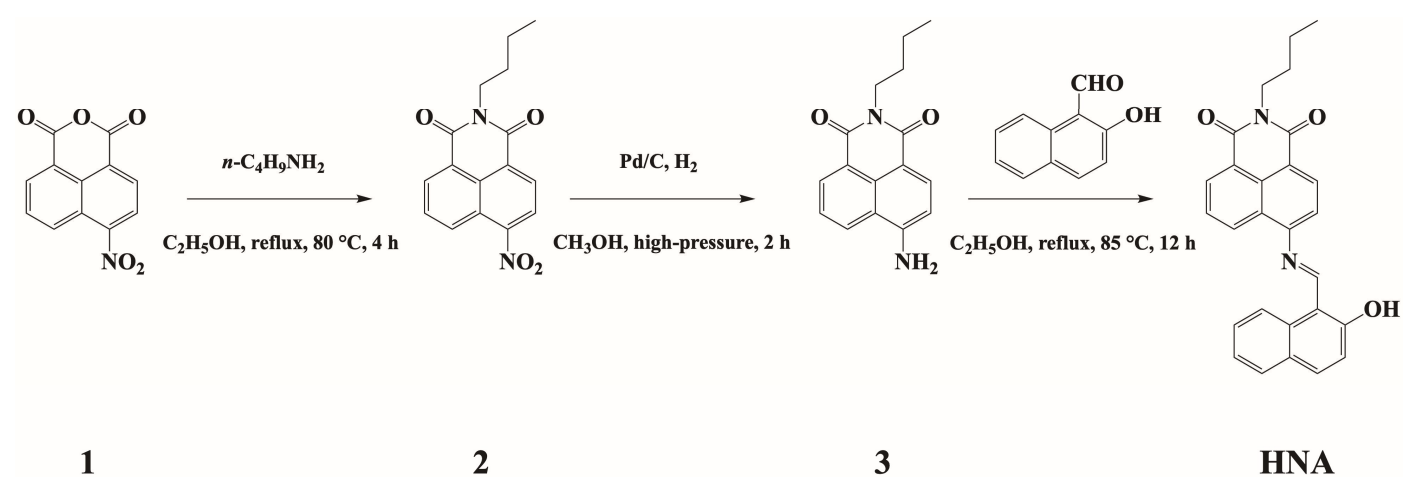

Scheme 1. The possible mechanism of HNA for the detection of $\mathrm{F}^{-}$.

\subsection{General preparation for the spectral experiments}

HNA was prepared to the solution $\left(10^{-4} \mathrm{M}\right)$ with the solvent of DMSO as stock solution. TBA salts with different anions $\left(\mathrm{F}^{-}, \mathrm{Cl}^{-}, \mathrm{Br}^{-}, \mathrm{I}^{-}, \mathrm{NO}_{3}^{-}, \mathrm{HSO}_{4}^{-}, \mathrm{SCN}^{-}\right.$and $\left.\mathrm{ClO}_{4}^{-}\right)$were prepared to the solution $\left(10^{-2} \mathrm{M}\right)$ with deionized water. $1 \mathrm{~mL}$ HNA stock solution was added to $10 \mathrm{~mL}$ volumetric flask, which was diluted to the concentration of $10^{-5} \mathrm{M}$ with DMSO solution. Next, $150 \mu \mathrm{L}$ different anions solutions were added to $10^{-5} \mathrm{M}$ HNA solutions by micro syringe, respectively. In order to investigate the ability of $\mathbf{H N A}$ for the detection of $\mathrm{F}^{-}$, different concentrations of $\mathrm{F}^{-}$were titrated to $10^{-5} \mathrm{M} \mathrm{HNA}$ solution, where the final concentrations of $\mathrm{F}^{-}$were ranging from 0 to 16 equiv.

\subsection{Detecting fluoride anion in real samples}

The standard addition method was introduced for the detection of $\mathrm{F}^{-}$in real samples. Different amounts of $\mathrm{F}^{-}$were added to $10^{-5} \mathrm{M}$ HNA solutions, where the final concentrations of $\mathrm{F}^{-}$were $1.0 \mu \mathrm{M}$, $5.0 \mu \mathrm{M}, 10.0 \mu \mathrm{M}, 50.0 \mu \mathrm{M}$ and $100.0 \mu \mathrm{M}$. The concentrations of $\mathrm{F}^{-}$in three real samples should be calculated on the basis of absorbance measured by UV-Vis spectra and linear normalization equation of absorbance and concentrations of $\mathrm{F}^{-}$.

\subsection{Computational details}

All the calculations were conducted with the Gaussian 09W software package [51]. The geometries were optimized by the B3LYP functional $[52,53]$. The 6-31G* basis set was utilized for all atoms. All geometry optimizations were carried out without symmetry constraints in conjunction with the PCM continuum solvation model [54], which used the solvent of water.

\section{Conclusions}

In summary, a colorimetric and ratiometric chemosensor HNA based on Schiff base was designed and synthesized. The color changes of HNA could be observed by the naked eye in the case of detecting $\mathrm{F}^{-}$, while other anions showed no color changes. HNA exhibited superior sensitivity and selectivity for the detection of $\mathrm{F}^{-}$with low LOD of $0.61 \mu \mathrm{M}$. The recognition mechanism of HNA for the detection of $\mathrm{F}^{-}$was further verified by the method of theoretical calculation. The interaction between HNA and $\mathrm{F}^{-}$was hydrogen bond, while deprotonation at high concentration of $\mathrm{F}^{-}$. Moreover, HNA could be used for detecting $\mathrm{F}^{-}$in real samples conveniently and precisely.

Supplementary Materials: Supplementary materials can be found at www.mdpi.com/xxx/s1.

Author Contributions: Conceptualization, Liu Yang and Yu-Long Liu; methodology, Liu Yang; software, YuLong Liu; validation, Liu Yang and Yu-Long Liu; formal analysis, Liu Yang; investigation, Cheng-Guo Liu; resources, Cheng-Guo Liu; data curation, Cheng-Guo Liu; writing-original draft preparation, Liu Yang; writing-review and editing, Ying Fu and Fei Ye; visualization, Yu-Long Liu; supervision, X.X.; project 
administration, Liu Yang and Yu-Long Liu; funding acquisition, Liu Yang and Yu-Long Liu. All authors have read and agreed to the published version of the manuscript.

Funding: This research was funded by the National Natural Science Foundation of China (No. 51903032), Natural Science Foundation of Heilongjiang Province (No. LH2019B002), Postdoctoral Science Foundation of Heilongjiang Province (No. LBH-Z19045). and the "Young Talents" Project of Northeast Agricultural University of Heilongjiang Province (No. 18QC64).

Acknowledgments: We thank the National Natural Science Foundation of China (No. 51903032), Natural Science Foundation of Heilongjiang Province (No. LH2019B002), Postdoctoral Science Foundation of Heilongjiang Province (No. LBH-Z19045). and the "Young Talents" Project of Northeast Agricultural University of Heilongjiang Province (No. 18QC64) for this work. Thanks for the support of Northeast Normal University for the part of theoretical calculations using the B3LYP/6-31G* method.

Conflicts of Interest: The authors declare no conflict of interest.

\section{Abbreviations}

$\begin{array}{ll}\text { MDPI } & \text { Multidisciplinary Digital Publishing Institute } \\ \text { DOAJ } & \text { Directory of open access journals } \\ \text { TLA } & \text { Three letter acronym } \\ \text { LD } & \text { linear dichroism }\end{array}$

\section{References}

1. Zhou, Y.; Zhang, J.F.; Yoon, J.Y. Fluorescence and colorimetric chemosensors for fluoride-ion detection. Chem. Rev. 2014, 114, 5511-5571.

2. Timerbaev, A.R. Element speciation analysis using capillary electrophoresis: twenty years of development and applications. Chem. Rev. 2013, 113, 778-812.

3. Kim, H.N.; Guo, Z.Q.; Zhu, W.H.; Yoon, J.; Tian, H. Recent progress on polymer-based fluorescent and colorimetric chemosensors. Chem. Soc. Rev. 2011, 40, 79-93.

4. Lee, M.J.; Jo, S.J.; Lee, D.Y.; Xu, Z.C.; Yoon, J. A new naphthalimide derivative as a selective fluorescent and colorimetric sensor for fluoride, cyanide and CO2. Dyes Pigm. 2015, 120, $288-292$.

5. Wu, N.; Zhao, L.X.; Jiang, C.Y.; Li, P.; Liu, Y.; Ye, F. A naked-eye visible colorimetric and fluorescent chemosensor for rapid detection of fluoride anions: Implication for toxic fluorine-containing pesticides detection. J. Mol. Liq. 2020, 302, 112549.

6. Kleerekoper, M. The role of fluoride in the prevention of osteoporosis. Endocrinol. Metab. Clin. North Am. 1998, 27, 441-452.

7. Sohn, H.; Letant, S.; Sailor, M.J.; Trogler, W.C. Detection of fluorophosphonate chemical warfare agents by catalytic hydrolysis with a porous silicon interferometer. J. Am. Chem. Soc. 2000, 122, 5399-5400.

8. Zhang, S.W.; Swager, T.M. Fluorescent detection of chemical warfare agents: functional group specific ratiometric chemosensors. J. Am. Chem. Soc. 2003, 125, 3420-3421.

9. Choi, A.L.; Sun, G.; Zhang, Y.; Grandjean, P. Developmental fluoride neurotox- icity: a systematic review and meta-analysis. Environ. Health Perspect. 2012, 120, 1362-1368.

10. Bashash, M.; Thomas, D.; Hu, H.; Martinez-Mier, E.A.; Sanchez, B.N.; Basu, N.; Peterson, K.E.; Ettinger, A.S.; Wright, R.; Zhang, Z.; Liu, Y.; Schnaas, L.; Mercado-Garcia, A.; Téllez-Rojo, M.M.; Hernández-Avila, M. Prenatal fluoride exposure and cognitive outcomes in children at 4 and 6-12 years of age in Mexico. Environ. Health Perspect. 2017, 125, 097017. 
11. Konieczka, P.; Zygmunt, B.; Namiesnik, J. Comparison of fluoride ion-selective electrode based potentiometric methods of fluoride determination in human urine. Bull. Environ. Contam. Toxicol. 2000, 64, 794803.

12. Yu, X.; Chen, J.; Li, Y.; Liu, H.; Hou, C.; Zeng, Q.; Cui, Y.; Zhao, L.; Li, P.; Zhou, Z.; Pang, S.; Tang, S.; Tian, K.; Zhao, Q.; Dong, L.; Xu, C.; Zhang, X.; Zhang, S.; Liu, L.; Wang, A. Threshold effects of moderately excessive fluoride exposure on children's health: a potential association between dental fluorosis and loss of excellent intelligence. Environ. Int. 2018, 118, 116-124.

13. Harrison, P.T. Fluoride in water: A UK perspective. J. Fluorine Chem. 2005, 126, 1448-1456.

14. Ayoob, S.; Gupta, A.K. Fluoride in drinking water: A review on the status and stress effects. Crit. Rev. Environ. Sci. Technol. 2006, 36, 433-487.

15. Dhillon, A.; Nairb, M.; Kumar, D. Analytical methods for determination and sensing of fluoride in biotic and abiotic sources: a review. Anal. Methods 2016, 8, 5338-5352.

16. Peng, B.X.; Wu, D.S.; Lai, J.H.; Xiao, H.Y.; Li, P. Simultaneous determination of halogens (F, Cl, Br, and I) in coal using pyrohydrolysis combined with ion chromatography. Fuel 2012, 94, 629-631.

17. Konieczka, P.; Zygmunt, B.; Namiesnik, J. Comparison of fluoride ion-selective electrode based potentiometric methods of fluoride determination in human urine. Bull. Environ. Contam. Toxicol. 2000, 64, 794803.

18. Liu, B.W.; Huang, Z.C.; Liu, J.W. Boosting the oxidase mimicking activity of nanoceria by fluoride capping: rivaling protein enzymes and ultrasensitive $\mathrm{F}^{-}$detection. Nanoscale 2016, 8, 13562-13567.

19. Moldoveanu, S.C.; Kiser, M. Gas chromatography/mass spectrometry versus liquid chromatography/fluorescence detection in the analysis of phenols in mainstream cigarette smoke. J. Chromatogr. A 2007, 1141, 90-97.

20. Hang, Y.; Wu, C. Ion chromatography for rapid and sensitive determination of fluoride in milk after headspace single-drop microextraction with in situ generation of volatile hydrogen fluoride. Anal. Chim. Acta. 2010, 661, 161-166.

21. Shao, J.; Lin, H. Rational design of a colorimetric and ratiometric fluorescent chemosensor based on intramolecular charge transfer (ICT). Talanta 2008, 77, 273-277.

22. Danjou, P.E.; Lyskawa, J.; Delattre, F.; Becuwe, M.; Woisel, P.; Ruellan, S.; Cazier-Dennin, F. New fluorescent and electropolymerizable $N$-azacrown carbazole as a selective probe for iron (III) in aqueous media. Sensors Actuators B Chem. 2012, 171-172, 1022-1028.

23. Wang, L.; Fang, G.; Ye, D.; Cao, D. Carbazole and triazole-containing conjugated polymer as a visual and fluorometric probe for iodide and mercury. Sensors Actuators B Chem. 2014, 195, 572-580.

24. Zhu, W.; Yang, L.; Fang, M.; Wu, Z.; Zhang, Q.; Yin, F.; Huang, Q.; Li, C. New carbazole-based Schiff base: Colorimetric chemosensor for $\mathrm{Fe}^{3+}$ and fluorescent turn-on chemosensor for $\mathrm{Fe}^{3+}$ and $\mathrm{Cr}^{3+}$. J. Lumin. 2015, 158, 3843.

25. Gross, D.E.; Mikkilineni, V.; Lynch, V.M.; Sessler, J.L. Bis-amidopyrrolyl receptors based on anthracene and carbazole. Supramol. Chem. 2010, 22, 135-139.

26. Chen, C.F.; Chen, Q.Y. A tetra-sulfonamide derivative bearing two dansyl groups designed as a new fluoride selective fluorescent chemosensor. Tetrahedron Lett. 2004, 45, 3957-3960.

27. Goswami, S.; Chakrabarty, R. An imidazole based colorimetric sensor for fluoride anion. Eur. J. Chem. 2011, $2,410-415$. 
28. Batista, R.M.F.; Costa, S.P.G.; Raposo, R.M.M. Selective colorimetric and fluorimetric detection of cyanide in aqueous solution using novel heterocyclic imidazo-anthraquinones. Sensors Actuators B Chem. 2014, 191, 791799.

29. Lee, G.W.; Kim, N.K.; Jeong, K.S. Synthesis of biindole-diazo conjugates as a colorimetric anion receptor. Org. Lett. 2010, 12, 2634-2637.

30. Tummachote, J.; Punyain, W.; Thanomsak, S.; Sirikulkajorn, A.; Tomapatanaget, B. Colorimetric N-butyl3,6-diamidecarbazole-based chemosensors for detection of fluoride and cyanide anions. Spectrochim. Acta Part A 2019, 214, 384-392.

31. Bissell, R.A.; De Silva, A.P.; Gunaratne, H.Q.N.; Lynch, P.I.M.; Maguire, G.E.M.; Sandanayake, K.R.A.S. Molecular fluorescent signalling with 'fluor-spacer-receptor' systems: approaches to sensing and switching devices via supramolecular photophysics. Chem. Soc. Rev. 1992, 21, 187-195.

32. Yang, L.; Liu, Y.L.; Liu, C.G.; Ye, F.; Fu, Y. Two luminescent dye@MOFs systems as dual-emitting platforms for efficient pesticides detection. J. Hazard. Mater. 2020, 381, 120966.

33. Zhu, B.C.; Yuan, F.; Li, R.X.; Li, Y.M.; Wei, Q.; Ma, Z.M.; Du, B.; Zhang, X.L. A highly selective colorimetric and ratiometric fluorescent chemodosimeter for imaging fluoride ions in living cells. Chem. Commun. 2011, 47, 7098-7100.

34. Qu, Y.; Hua, J.; Tian, H. Colorimetric and ratiometric red fluorescent chemosensor for fluoride ion based on diketopyrrolopyrrole. Org. Lett. 2010, 12, 3320-3323.

35. Zimmermann-Dimer, L.M.; Machado, V.G. Chromogenic anionic chemosensors based on protonated merocyanine solvatochromic dyes: influence of the medium on the quantitative and naked-eye selective detection of anionic species. Dyes Pigm. 2009, 82, 187-195.

36. Du, W.W.; Xu, J.; Li, H.X.; Feng, C.C.; Yu, M.M.; Li, Z.X.; Wei, L.H. Naked-eye and fluorescence detection of basic $\mathrm{pH}$ and $\mathrm{F}^{-}$with a 1,8-naphthalimide-based multifunctional probe. RSC Adv. 2015, 5, 15077-15083.

37. Sadak, O.; Sundramoorthy, A.K.; Gunasekaran, S. Highly selective colorimetric and electrochemical sensing of iron (III) using Nile red functionalized graphene film. Biosens. Bioelectron. 2017, 89, 430-436.

38. Huang, L.; Sun, D.W.; Pu, H.; Wei, Q.; Luo, L.; Wang, J. A colorimetric paper sensor based on the domino reaction of acetylcholinesterase and degradable $\gamma-\mathrm{MnOOH}$ nanozyme for sensitive detection of organophosphorus pesticides. Sens. Actuators B 2019, 290, 573-580.

39. Dhiman, S.; Ahmad, M.; Singla, N.; Kumar, G.; Singh, P.; Luxami, V.; Kaur, N.; Kumar, S. Chemodosimeters for optical detection of fluoride anion. Coord. Chem. Rev. 2020, 405, 213138.

40. Yang, S.; Liu, Y.; Feng, G. Rapid and selective detection of fluoride in aqueous solution by a new hemicyanine-based colorimetric and fluorescent chemodosimeter. RSC Adv. 2013, 3, 20171-20178.

41. Gu, J.; Lin, Y.; Chia, Y.; Lin, H.; Huang, S. Colorimetric and bare-eye determination of fluoride using gold nanoparticle agglomeration probes. Microchim Acta. 2013, 180, 801-806.

42. Turan, I.S.; Akkaya, E.U. Chemiluminescence sensing of fluoride ions using a self-immolative amplifier. Org. Lett. 2014, 16, 1680-2168.

43. Christiansona, A.M.; Gabbaïa, F.P. Anion sensing with a Lewis acidic BODIPY-antimony(V) derivative. Chem. Commun. 2017, 53, 2471-2474.

44. Qu, Y.; Hua, J.; Tian, H. Colorimetric and ratiometric red fluorescent chemosensor for fluoride ion based on diketopyrrolopyrrole. Org. Lett. 2010, 12, 3320-3323. 
45. Pramanik, S.; Zheng, C.; Zhang, X.; Emge, T.J.; Li, J. New microporous metal-organic framework demonstrating unique selectivity for detection of high explosives and aromatic compounds. J. Am. Chem. Soc. 2011, 133, 4153-4155.

46. Yang, L.; Liu, Y.L.; Liu, C.G.; Fu, Y.; Ye, F. A built-in self-calibrating luminescence sensor based on RhB@ZrMOF for detection of cations, nitro explosives and pesticides. RSC Adv. 2020, 10, 19149-19156.

47. Li, L.; Gao, S.; Yang, L.; Liu, Y.L.; Li, P.; Ye, F.; Fu, Y. Cobalt (II) complex as a fluorescent sensing platform for the selective and sensitive detection of triketone HPPD inhibitors. J. Hazard. Mater. 2021, 404, 124015.

48. Ye, F.; Wu, N.; Li, P.; Liu, Y.L.; Li, S.J. A lysosome-targetable fluorescent probe for imaging trivalent cations $\mathrm{Fe}^{3+}, \mathrm{Al}^{3+}$ and $\mathrm{Cr}^{3+}$ in living cells. Spectrochim. Acta Part A 2019, 222, 117242.

49. Fu, Y.; Pang, X.X.; Wang, Z.Q.; Chai, Q.; Ye, F. A highly sensitive and selective fluorescent probe for determination of $\mathrm{Cu}$ (II) and application in live cell imaging. Spectrochim. Acta Part A 2019, 208, 198-205.

50. Ye, F.; Liang, X.M.; Xu, K.X.; Pang, X.X.; Chai, Q.; Fu, Y. A novel dithiourea-appended 1,8-naphthalimide chemosensor for dual recognition of $\mathrm{Hg}^{2+}$ and $\mathrm{Ag}^{+}$and its bioimaging. Talanta 2019, 200, 494-502.

51. Frisch, M.J.; Trucks, G.W.; Schlegel, H.B.; Scuseria, G.E.; Robb, M.A.; Cheeseman, J.R.; Scalmani, G.; Barone, V.; Mennucci, B.; Petersson G.A. and et al. Gaussian 09, revision A.02; Gaussian Inc.: Wallingford CT 2009.

52. Becke, A.D. Density-functional thermochemistry. III. The role of exact exchange. J. Chem. Phys. 1993, 98, $5648-5652$.

53. Lee, C.; Yang, W.T.; Parr, R.G. Development of the Colle-Salvetti correlation-energy formula into a functional of the electron density. Phys. Rev. B: Condens. Matter Mater. Phys. 1988, 37, 785-789.

54. Tomasi, J.; Mennucci, B.; Cammi, R. Quantum mechanical continuum solvation models. Chem. Rev. 2005, 105, 2999-3093. 